On the nloht of Angust 18th-the last night of the present series of attacks-ahe wrote a short letter to her

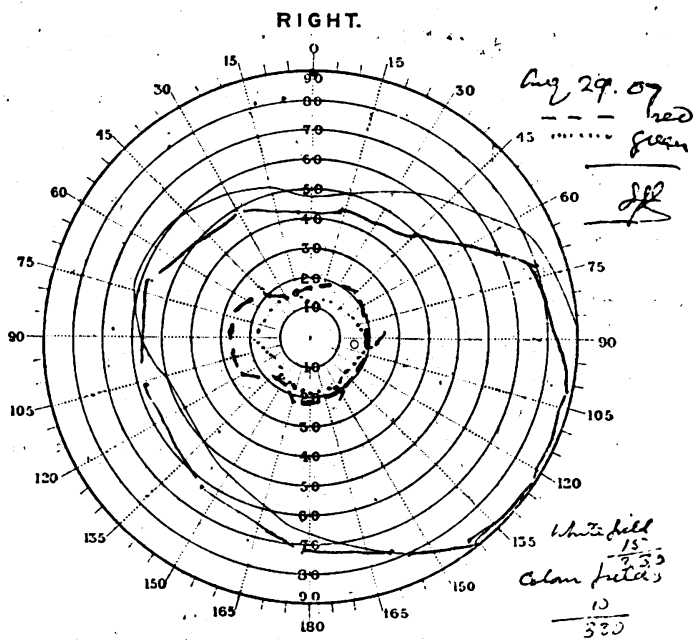

music teacher together with the following essay, puttlng it Into an envelope and addressing it correctls, as she alterwards informed us :

Sorata Form

Bonats Form is divided into three forms

1. Introduction.

2. Development.

3ere follow two lines crossed out.) The Introduction conslsts of two sipple themes both writien ont shortly (? strictly) on the Tonia. The Development is sometimes very long and In it both themes are warked out thoroughly at great length. The Development is always written in the Dominant. Recapitulation is a brief summary of the whole piece which is written agsin in the Tonic. Bome sonstas also contain a short written again in the Tonlc. Some sonstas also contain a short Introductory Theme, and snatches of this Theme will be found are generally found running all through th
Instance is the "Pathétique" of Beothoren.

Thls essay, as well as the accompanying letter, was written quite cleary in pencll, and was indited in the dim light in which, in ner waking state, she had pre. vioualy been unable to write with any degree of legibllity.

From this time onwards there was no recurrence of the sleep-wolking, and the patient was discharged a week or two later in good healtb. Her doctor has recently informed me that "ghe is much better and earning her living as a typewriter, but has occasional night wanderings."

The phrsical examination showed little of importance. The chest, heart, and abdomen were normal, nutrition and digestion were good, the urlne was free from albumen and sugar, and there was only a slight degree of constipation. The superficial and deep reflexes -were, if anything, a little exaggerated. I conld myself detect no areas of altered tactile senslbility; but Mr. Jameson Evans, who kindly made the examination of the fields of vision here recorded, discovered a small patch of ansesthesle just above and to the onter side of each upper eyelld. The accompapying figures show the fields of vision in each eye and the colour field in the right eye. These were taken on Angust 29th, and Mr. Jameson Evans Informs me that they give practically normal results, though the colour fieIds are perhaps a llttle emall.

I think that there is evidence in this case of the existence of abnormal acuity of vision during the somnambulistic atate. It is of course possible that, after coming to herself on the night of Angust 17th, the patient mlght have recognized the object of the test to which she was subjected, and that a desire to arouse interest might have led her to voluntarly make the uneucceseful attempt at writing shown in the second lllustration. The housephysician and the nurses, however, were fully convinced that the light in the ward was quite insufficlent to allow of any writing or work to be carrled out by any normal Individual, and I belleve that the results of the test may be accepted as reliable. It is worthy of note that the events which apparently occupled ber mind during the sleep-walking were not forgotten when awake. Her father's desth, the circumstances of the relation to whom ahe wrote, and the mugical interest, were all fully realized
In the waking condition. In this, respect, the case differs from many of the Instances of hysterieal somnambullsm

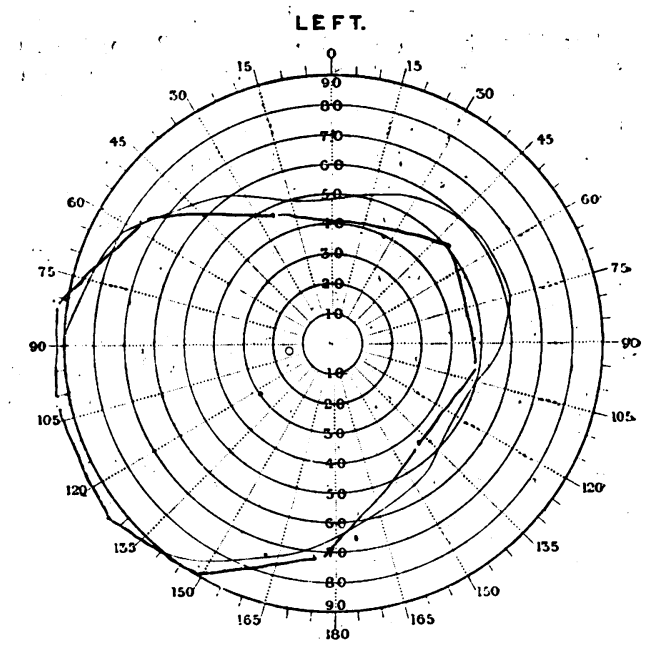

rfcorded, sepecially in France, in which the ideas present during the somnambaliem have been entirely forgotten in the waking state.

\section{A CASE OF MERYCISM.}

BY H. F. LEOHMERE TAYLOR, M.A., M.B., D.P.H.ED,

Is view of Dr. Brockbank's paper of February 23rd, 1907. it may be of Interest to record the following case of merycism in a boy seen recently as an out-patient at the Mission Hospital, Jalalpur-Jattan, Punjab.

A boy of the village farming class, said to be 14 years of age, but hardly looking so much, was brought by his mother for pains in the arms. She herself is a leper, showing a perfect clinical picture of the unmired nervouf form of the disease, from which she says she has suffered for twenty-five years. She was afraid that her son might be developing the same condition and wished to have him examined. In the course of the Investigation it came to light that he was a habitual ruminant. He and his mother, though questioned and cross-questioned in various ways, both gave a perfectly consistent account of the condition.

About four years ago he began to have return of food into bis mouth immediately atter meals. This seems to have begun when he was attending school and was in the hablt of running home and eating a meal hurriedly during school hours. What came back was alightly bitter in taste, and at first he used to splt it out, with the result that he had a great feeling of nausea and hls mouth became "as bitter as poison" to use his own words. Soon he learned that by swallowing the inouthfals as they came up he could escape the unpleasant symptoms, and the hablt of doing 80 was speedily cstablished. He attended school for only a few monthe, and then went back to work on the farm, having a good deal to do with cattle; "Imitation," however, does not seem to afford a sufficient explanation of the habit.

His present condition is that his food, which he now chews well and eats at the usual rate, begins to regurgltate in mouthfols as soon as the meal is finlshed; ne does not rechew it as it comes ap quite solt; it is still slightly bitter in taste, but not enough so to be unpleasant; on the other hand, he derives no great pleasure from the process. If, however, he spits out a mouthful, he still suffers from a very bad taste In his morith, associated with so much nausea and giddiness that he says he is unsble to stand without support. The action is quite automatic, and goes on regularly till he begins to feel hungry for his next meal, when it ceases. He has no control over it whatever, nor has he any power of producing emesis at will. He does not suffer in the least from dyspepsla, but is usually somewhat constlpated, a very common complaint in the Papjab.

His food, taken twice a day according to the custom of the country, is that of the men of his class, consisting chlefly of thin unleavened cakes of wheat or barley flow 
(ohapatties) along with a little lentil pottage (dal) or stew id green vegetables or butter; raw vegetables, such as carrots, turnips, and radishes, are probbbly freely Indulged in; meat is a very occasional luxury. Milk and lassi (sour butter milk) are the only drinks except water. Fluids "return". even more markedly than solids.

There is nothing of interest in the family history, with the exceptlon' of the mother's condition. There were three other chlldren; two boys died in infancy of smallpox, and a sister in adult age after childbirth. The mother knows of no one else in the famlly connexion who was in the hablt of chewing the cud, and she bas never heard of any other person who exhlblted the peculiarity.

There is nothing else of importance in the condition of the boy himself. The pain from which he suffers seems to be rheumatic. Careful examlnation falled to discover any patches of anaesthesls or nervous disorder, suggestive of inciplent leprosy or other general disease.

\section{MEMORANDA : \\ MEDICAL, SURGICAL, OBSTETRICAL.}

\section{EXCESSIVE PATELLAR REFLEX OF NERVOUS ORIG!N.}

The following cases may be of interest in connexion with different points in Dr. Parkes Weber's valuable paper and Dr. Hobhouse's letter.

1. A mav, suffering apparently from acute alcoholic insanity, showed Bablnskl's slgn, but no other symptom of organic disease. As his mental state improved the extensor response gradually gave place to one of flexion. After this the mental improvement stopped, and signs of genersl paralysis began to appear. It may be held that the Babinski sign was due to early general paralysis, but against this are the facts that it disappeared as the effects of the alcohol wore off, and was disappeared as the effects of the alcohol wore off

2. A woman, aged about 45, suffering from - melancholia, showed Bablnski's sign and a very marked wrist-jerk. She was under observation for some months, . during which time her mental condition Improved greatly, but recovery was not complete. The wrist-jerk diminished considerably, but the extensor plantar reflex was still present when she was last seen. In this case, of course, the . Babinskl sign mag have been an early eymptom of some organic change that had not become manlfest when I last saw the patient.

If the extensor response is of functional origin in Infants-as presumably it is-why may it not sometimes be so in adults too?

3. A young girl with acute mania, from which she recovered in a fow months, showed exaggerated knee-jerks when first seen. Some time later both knee-jerks were absent. Methods of relnforcement were not practicable. Later still, one kneejerk was present, the other absent. On recovery both were present.

4. A woman with syphilitic disease of the brain came under observation with ankle clonus. Thls disappeared later withont any obvious change having occurred in the organic disease.

A slight degree of ankle clonus is well known to be common in functional disease and slight patellar clonus may occar.

It is not uncommon (so far as my experience goes) for the Insane to show contraction of certain individual muscles when they are lightly tapped, like that displayed. only more universally, by some emaciated patients and by those 'In the lethargic stage of hypnotism. The muscle most frequently affected seems to be the vastus externus, sometimes of one side only; others that I have seen are the deltoid, the pectoralis major, the triceps, the blceps, and the muscles of the hypothenar eminence. The patients who exhlbit thls phenomenon are mostly general paralytics or chronle alcoholicg, in either case having organlc changes in the braln; but $I$ have geen it in a case of acute alcoholic insanity that recovered in less than a month, and in a case of simple melancholia which became chronic. This association with cases that are probably free from organic change, and the similarity of the phenomenon to that occurring in emaclation and the hypnotic state, polnt to its :being due to a functional disorder of the cortex, just as ts the exaggerated patellar reflex, in Dr. Parkes Weber's opinlon.: Perhaps Dr. Weber might haye added absence of the knee-jerk to the, canditions that may sometimes depend on functional cortical disturbance. The theory that it is necessarily due to the catting off of inhibitive currents that pass down the pyramidal tract is hard to reconcile with its occurrence in deep sleep, in old age, in hypochondrissis, in emaclated persons, and $\epsilon$ ven in the healthy. The results of Jendrassik's method of reinforcement are also hard to reconcile with the arrest of inhibition theory. No doubt it is said that this method acts by distracting the attention, and so cutting off the inhibiting currents; but, in the first place, the method may still prove successful (in cases where the reflex is not obtainable without it), even if the patient deliberately directs his attention to the knee while pulling on his hands and, secondly, it was shown by the late Dr. Ch. Félé that the action of one set of muscles does not diminish, but actually increases, the energy of the cerebral cortex in other directions.

Tunbridge Wells.

P. C. Вмгтн, M.D.Durh.

\section{MIDDLE MENINGEAL HAEMORRHAGE :} TREPHINING : RECOVERY.

THE statistics of von Bergmann, giving 16 recoveries out of 99 cases of middle meningeal haemorrhage, are an excuse for recording the following case :

A young man, aged 22 , fell off a coal cart on to his head at 5.30 p.m. on June 1st; he was unconscious for ten minutes; he was then given sixpennyworth of brandy by an onlooker, and proceeded home by train. He then had some tea and bread-and-butter. At 8.15 p.m. he began to vomit, and complained of pain in his head; a medical man saw hlm, and at 9.30 p.m. he became drowey ; during the night his breathing was noigy, and he began to throw his arms and lege about. There were occasional interval when he was consclous, and he spoke several times; he becsme quite unconsclous during the esrly morning. At 8.30 p.m. on June 2 d-over twenty-lour hours after the accldent-he was admitted into hospltal completely unconsclous; breathing stertorous; pulse 52 ; pupils markedly unequal, the right fully dilated and the left of a natural size; both were insensible to light, and there was no conju actival $\mathbf{r}_{\text {f flex }}$; both arms and legs were In a constant state of movement; a slight boggy feeling was detected over the right temporal area. About 9 p.m., after consultation with my colleague, Dr. Bell (to whom I am much indebted for his help), a trephine was applied over the site of the right middle meningeal artery and at once blood clot was exposed; on enlarging the opening a lorge $\epsilon$ travasation of blood was visible, which was washed away with saline solution; as no bleeding point was seen, the opening was further enlarged with Hoffman's forceps towards the 'zygoma; a bleeding vessel was finally found low down and thts was underrun; the flap was replaced and a drainage tube left in the wound, as the brain did not readily expand.

At 530 next morning patient could answer questions, although still drowgy. He gradually made a good recovery and has been in Iall work for three months. There was total paralysis of the third nerve on the right side for a time, but this gradually dis appeared.

In this case there was no history as to which side was injured, and both arms and legs were in a constant state of movement; the slight bogginess over the right tem. poral region and the marked dilatation of the right pupil determined the site for operation. With regard to this dilatation of the pupil on the affected side Jacobron says: "It is a rare but most valuable slgn; taken with other evidence of middle meningeal extravasation, this condltion of pupll points to a large clot reaching down into the base and pressing forwards on the sphenoldal fissure and thus compressing the th rd nerve." This was proved at the operation and also by the third nerve paralysis.

There was a well.marked lucid interval of four hours. Miles and Thompson say the prognosis is grave when operation is delayed beyond twelve to elghteen hours; in this case twenty-seven hours elapsed belore the man came into hospl ial.

I am indebted to the late House-Surgeon, Dr. Mactavish, for notes of the case and for his care In the aftertreatment. 